\title{
Relationship between Oil Uptake and Moisture Loss during Deep Fat Frying of Deboned Chicken Breast Meat
}

\author{
Lamin S. Kassama1, Michael Ngadi² \\ ${ }^{1}$ Department of Food and Animal Sciences, Alabama A\&M University, Normal, USA \\ ${ }^{2}$ Department of Bioresource Engineering, McGill University, Ste-Anne-de-Bellevue, Canada \\ Email: Lamin.kassama@aamu.edu
}

How to cite this paper: Kassama, L.S. and Ngadi, M. (2016) Relationship between Oil Uptake and Moisture Loss during Deep Fat Frying of Deboned Chicken Breast Meat. $A d$ vances in Chemical Engineering and Science, 6, 324-334.

http://dx.doi.org/10.4236/aces.2016.64033

Received: June 28, 2016

Accepted: August 20, 2016

Published: August 23, 2016

Copyright $\odot 2016$ by authors and Scientific Research Publishing Inc. This work is licensed under the Creative Commons Attribution International License (CC BY 4.0).

http://creativecommons.org/licenses/by/4.0/ (c) (7)

Open Access

\begin{abstract}
The relationship between moisture loss and oil uptake at different combination of Frying Oil Temperatures (FOT) and time during deep-fat frying of chicken meat was investigated in this study. Chicken meat samples were diced and fried at different FOT $\left(170^{\circ} \mathrm{C}, 180^{\circ} \mathrm{C}\right.$, and $\left.190^{\circ} \mathrm{C}\right)$ in an industrial fryer for periods varying from 5 to $900 \mathrm{~s}$. Fat analysis was accomplished in a soxhlet extraction apparatus with petroleum ether solvent. Prior to fat analysis samples were freeze dried and the moisture analysis was based on the standard AOAC standard method. The results show that a cook value of $415 \mathrm{~s}$ was found to give the most ideal sensory characteristics. The relationship between moisture loss and oil uptake during the initial phase of frying $(<45 s)$ was erratic and appeared to be independent of frying oil temperature. A linear correlation existed $(r=0.97)$ between moisture loss and frying time. Oil uptake was positively correlated to moisture loss in the range of frying times $45 \mathrm{~s}$ to about $600 \mathrm{~s}$. After $600 \mathrm{~s}$, oil uptake tended to equilibrate while moisture loss continued in the quasiequilibrium state. The relationship between moisture loss and oil uptake is an important phenomenon in the context of characterizing the physical properties of fried product. The rate of oil uptake was 1.64 and $1.74 \mathrm{~g} / \mathrm{s}$ for the FOT $180^{\circ} \mathrm{C}$ and $190^{\circ} \mathrm{C}$, respectively, and the rate $(1.35 \mathrm{~g} / \mathrm{s})$ at $\mathrm{FOT} 170^{\circ} \mathrm{C}$ was significantly $(\mathrm{P}<0.05)$ lower.
\end{abstract}

\section{Keywords}

Cook-Value, Pores, Frying, Oil Uptake, Chicken Meat, Moisture

\section{Introduction}

Despite the fact that excessive consumption of foods that are deep-fat fried has been 
linked to coronary diseases and other forms of cancer [1], fried foods have remain popular due to their unique taste and rapidity of preparation. In consequence, there has been interest in determining how to minimize oil absorption while preserving the organoleptic characteristics that are favorable to the consumer, such as crispiness, color, and flavor [2] [3]. Chicken is one of the most popular deep-fried foods in North American. Raw chicken can contain UP to 5\% saturated fats, depending on the part and whether with skin or skin removed. Although edible films coatings (battered) have been shown to reduce fat absorption in chicken meat [4]-[6], hence there is limited information concerning fat absorption mechanisms of uncoated chicken.

Most of the research on the mechanism of fat absorption has been conducted on potatoes and other plant-based products such as tortillas and falafelballs, whereas little information is available on meat products. It has been shown that fat absorption by thin potato slices is directly related to the amount of moisture lost; hence moisture loss is directly proportional to the square root of frying time, and the frying oil temperature has indirect effect on oil absorption [7]-[9]. These relationships have been studied for various foods [8]-[14]; however, there is some disagreement as to the mechanisms of fat absorption. Moreover, fundamental differences in composition and structure of various food materials make it difficult to generalize results, even though foods in general are considered to be hygroscopic porous media [1]. Hence, the objective of this study was to evaluate the relationships between moisture loss and oil uptake at different combinations of oil temperature and frying time as a first step in elaborating the mechanisms of the combined heat and mass transfers involved.

\section{Materials and Methods}

\subsection{Materials}

Fresh de-boned chicken breast was used throughout this study. Samples were purchased from a local supplier. The stock was stored in a freezer at $-20^{\circ} \mathrm{C}$ until used. It was then thawed in a refrigerator at $4^{\circ} \mathrm{C}$ for 24 to $36 \mathrm{~h}$ before commencement of the experiment.

\subsection{Sample Preparation}

Frozen samples were removed from a freezer and thawed in a refrigerator at $4^{\circ} \mathrm{C}$ for 24 h. The samples were diced into cubes of approximately $5 \mathrm{~cm} \times 3 \mathrm{~cm} \times 1 \mathrm{~cm}( \pm 0.5 \mathrm{~cm})$. Minor departures from the target dimension were due to the irregular shape of the chicken breasts.

\subsection{Frying}

A programmable computerized pressure deep-fat fryer (Henny Penny Computron 7000 Pressure Fryer, Model 500C, Henny Penny Corporation, Eaton, OH.), with a fat holding capacity of about $30 \mathrm{~L}$. A liquid shortening (Can Amera Food, Oakville, ON) was used for frying and the sample to oil weight ratio was about 1:480. The fresh oil was preheated at $170^{\circ} \mathrm{C}$ for $2 \mathrm{~h}$ and then adjusted to one of the three oil temperatures used 
for frying in this study $\left(170^{\circ} \mathrm{C}, 180^{\circ} \mathrm{C}, 190^{\circ} \mathrm{C}\right)$. Three samples were fried at each of twenty frying times: $5,10,15,20,30,45,60,90,120,150,180,210,240,300,360,420$, $480,540,600$, or $900 \mathrm{~s}$. Frying times were randomly chosen within temperature and the triplicates were run sequentially at the given frying time. This procedure was preferred to a completely randomized approach, which would have resulted in significant time lapses for heating and cooling the oil. The fried samples were removed from the frying oil, cooled at room temperature, weighed using a TR-4102D scale, (Denver Instrument Co., Denver, CO), placed in plastic Zip-Lock sample bags, and frozen at $-20^{\circ} \mathrm{C}$ in a freezer prior to further analysis.

\subsection{Cook-Value}

The frying condition was adjusted to assure cooking at the center to attain a satisfactory texture. The center temperature of the chicken meat strip was measured with a T-type thermocouple (copper-constantan) placed at the geometric center of the product. The center temperatures were then used to determine the cook-value ( $\mathrm{C}$-value), or cooking time equivalent at $100^{\circ} \mathrm{C}$, as defined in Equation (1) [15] [16]:

$$
C=\int_{T_{i}}^{T_{f}} 10^{\left(T-T_{r}\right) / z_{c}} \mathrm{~d} t
$$

where, $T_{i}$ is the initial temperature, $T_{f}$ the final temperature, $T_{r}$ is the reference temperature $\left(100^{\circ} \mathrm{C}\right), Z_{c}$ is the temperature required for 10 -fold increase in the reaction rate for chemical, physical or sensory change, taken as $24^{\circ} \mathrm{C}$ according to the value reported by Dagerskog [16] based on the rheological property of cooked meat.

\subsection{Drying and Moisture Analysis}

Drying of the fried samples prior to freeze drying was conducted using a freeze dryer (ModulyOD-115, Thermo Savant, Holbrook, NY) for $30 \mathrm{~h}$. All the samples were dried at a temperature of $-50^{\circ} \mathrm{C}$ and a pressure of $750 \mu \mathrm{m} \mathrm{Hg}$. Procedure for the moisture analysis for the fried chicken samples place in an oven at $100^{\circ} \mathrm{C}$ for $18 \mathrm{~h}$ based on the recommended AOAC 960.42 [17]. The initial mass of the samples prior to oven drying and the final mass of the dried product were determined using a TR-4102D scale (Denver Instrument Co., Denver, CO).

\subsection{Fat Analysis}

The freeze-dried fried samples were ground using a blender (Proctor-Silex, model E160B, Picton, ON). The ground samples $(2-4 \mathrm{~g})$ were weighed with an electronic scale (TR-4102D, Denver Instrument Co., Denver, CO) and placed in a thimble. Some sea sand was added to the sample in the thimble and mixed with a glass rod. Fat was extracted in a solvent extractor (SER148, VelpScientifica, Usmate, Italy) using petroleum ether. The mass of the glass extraction cups with a few boiling stones was recorded and $50 \mathrm{~mL}$ of petroleum ether was added to each cup. The thimbles were then inserted to the magnetic connector of the extraction unit. Procedure followed as recommended by AOAC Method 960.39 [18] and also (SER148, Operation manual). The 
thimbles were immersed in the boiling solvent for $30 \mathrm{~min}$ and then submitted to $60 \mathrm{~min}$ of reflux washing and $30 \mathrm{~min}$ of drying to recover the solvent. The extracts were further dried in a convection oven (Isotemp 700, Fisher Scientific, Pittsburgh, PA) at $125^{\circ} \mathrm{C}$ for $30 \mathrm{~min}$. The sample cups were cooled in a desiccator and subsequently weighed. The oil content (OC) dry basis, was computed for each sample using the following relationship:

$$
\text { OC }(\%)=\frac{\text { mass of oil extracted }}{\text { mass of dried sample }} \times 100
$$

\subsection{Experimental Design and Statistical Analysis}

Experiment was based on two factor factorial design. The two factors were frying temperature and frying time. Treatments were applied at 3 levels of frying temperature $\left(170^{\circ} \mathrm{C}, 180^{\circ} \mathrm{C}, 190^{\circ} \mathrm{C}\right)$, and 20 levels of frying time $(5,10,15,20,30,45,60,90,120$, $150,180,210,240,300,360,420,480,540,600$, or 900 s). Data was analyzed using ANOVA procedure for analysis of variance using the SAS 9.0 statistical programs and Duncan's group mean comparison test was used for the mean comparisons of significant treatments. All experiment was carried out in triplicates and statistical tests were performed at $5 \%$ level of significance.

\section{Results and Discussion}

\subsection{Moisture Loss and Oil Uptake}

The evolution of moisture loss is shown in Figure 1(a) and Figure 1(b), and the oil uptake in Figure 2(a) and Figure 2(b). Figure 1(a) and Figure 2(a) focus on an observation of the first $45 \mathrm{~s}$ of frying, during which the behaviors tend to be erratic,

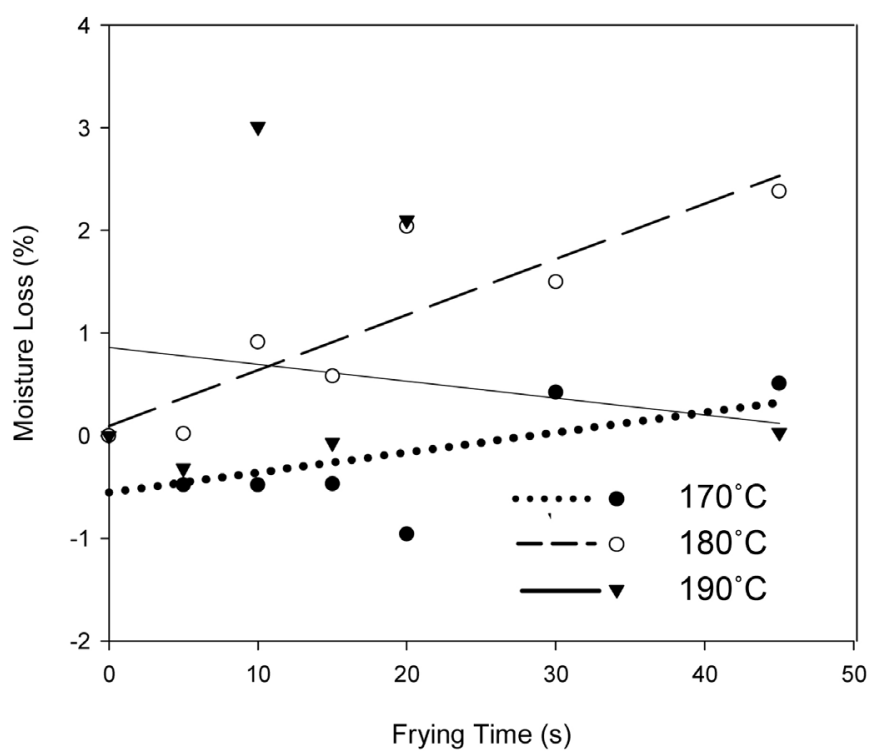

(a)

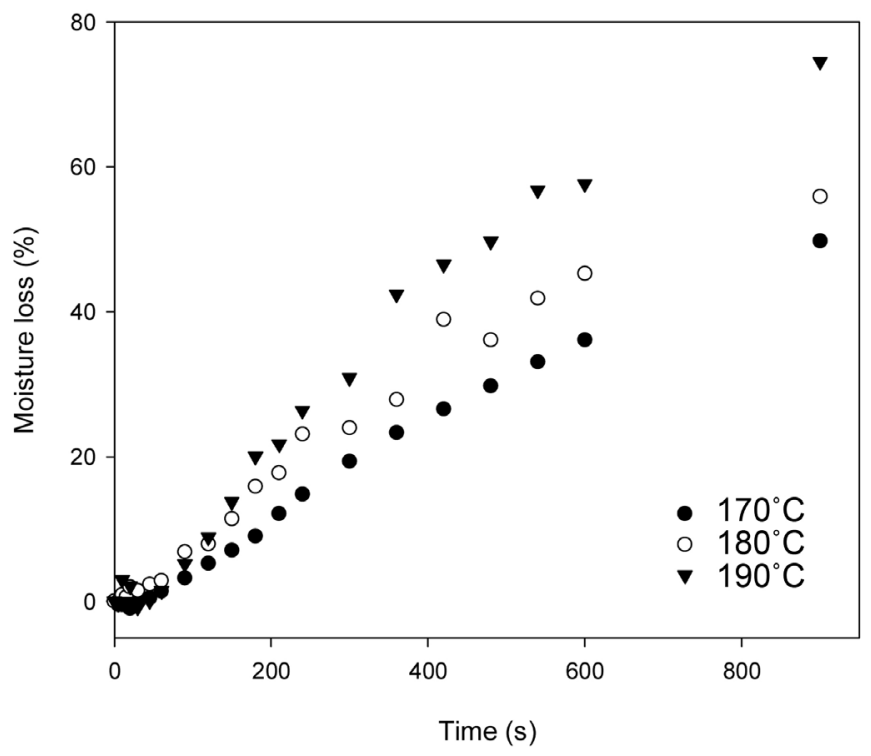

(b)

Figure 1. Moisture loss as a function of frying oil temperatures in chicken breast during deep-fat frying: (a) moisture loss at times <45 $\mathrm{s}$ and (b) moisture loss at times $0-900 \mathrm{~s}$. 


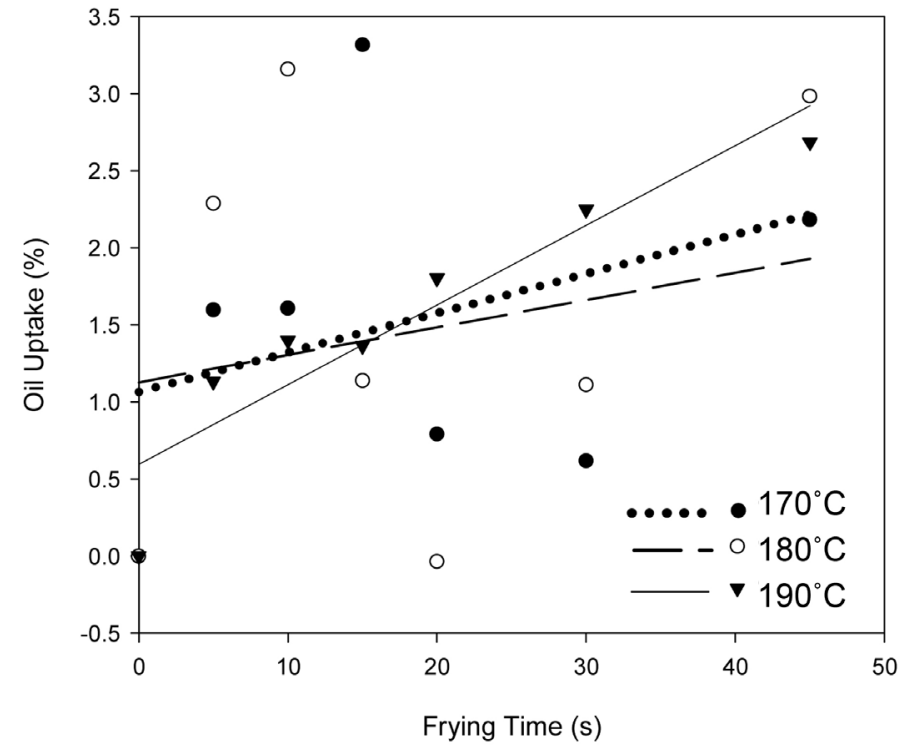

(a)

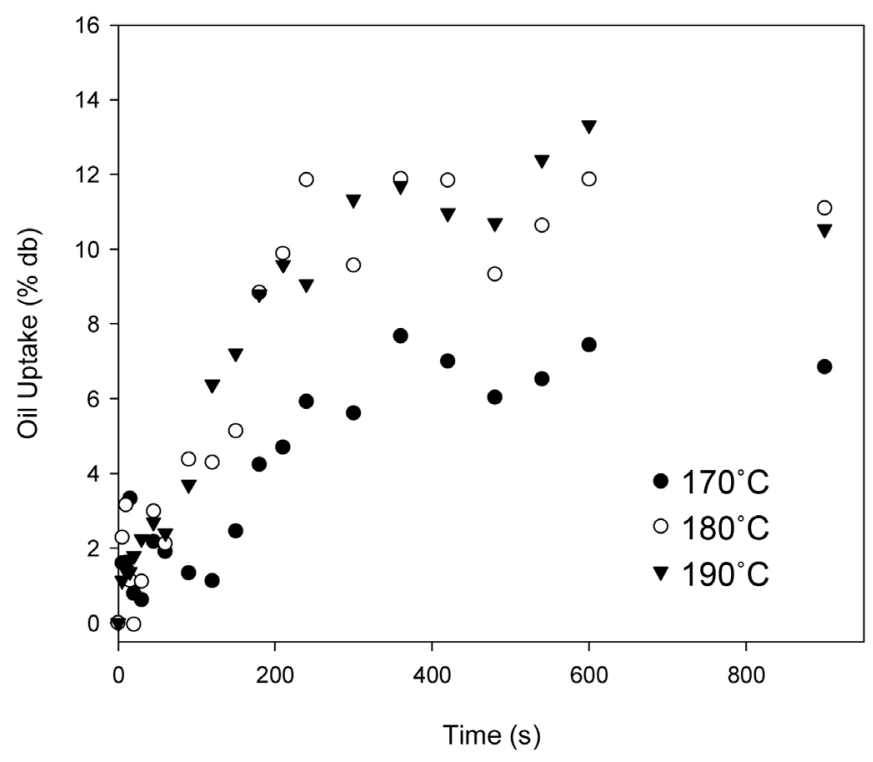

(b)

Figure 2. Oil uptake as a function of frying oil temperatures in chicken breast during deep-fat frying: (a) moisture in the range (<45 s) and (b) (>45 s).

probably due to the constant rate period, a phenomenon that applies to the initial state in drying. In the case of moisture loss, the data exhibit a significant linear tendency at $180^{\circ} \mathrm{C}(\mathrm{r}=0.89)$, but are random at the other temperatures $\left(\mathrm{r}=0.56\right.$ at $170^{\circ} \mathrm{C}, \mathrm{r}=0.17$ at $\left.190^{\circ} \mathrm{C}\right)$.

For oil uptake, the data was linear at $190^{\circ} \mathrm{C}(\mathrm{r}=0.93)$ but random at $170^{\circ} \mathrm{C}$ and $180^{\circ} \mathrm{C}(\mathrm{r}=0.24,0.17$ respectively). Singh [13] has described the initial phase to be surface-boiling phase, hence causing an instability due to turbulence behavior of the frying oil near the surface when the cold product comes into contact with the high oil temperature causing the boiling of surface water and bubbling up of water vapor from beneath the surface. Although the trend in oil uptake is significant at $190^{\circ} \mathrm{C}$, the observations are within the scatter for the other temperatures; thus, it appears reasonable to conclude that oil uptake in this short lapse of time is mainly due to surface adhesion, penetration likely being inhibited by the movement of water in the surface layer. The lack of adequate heat energy to induce transport of moisture may also play a significant role. With respect to a similar phenomenon observed in a study of potato frying, Bouchon et al. [19] also suggested that evaporative cooling at the surface could result in inadequate heat transfer in the initial phase.

In the second phase ( $>45 \mathrm{~s}$ ), moisture loss increases almost linearly (Figure 1(b)), as also reported for potato strips by Mittelman et al. [8], with a slight convexity (>600 s) representing the onset of mass-transfer limitations. The effect of frying oil temperature (FOT) becomes more evident (separation of curves) after about $175 \mathrm{~s}$, moisture loss being significantly affected by FOT. Oil uptake responds in a similar fashion to time and temperature up to about $400 \mathrm{~s}$ (Figure 2(b)), after which the percent of oil declines for a short period and then recovers. The temporary expulsion of absorbed oil may be 
indicative that the forces tending to drive the remaining moisture out of the porous structure are reopening the oil-blocked exits near the surface were case hardening disrupt the pore structure [1] [20]. Changes in pore structure as frying progresses with time and shrinkage may also contribute to the overall phenomenon [10]. Oil uptake may reach a quasi-equilibrium state when the proteins are fully degraded, hence become unstable and causing the oil absorption to fluctuate. Although, processing at $170^{\circ} \mathrm{C}, 180^{\circ} \mathrm{C}$ and $190^{\circ} \mathrm{C}$ for $900 \mathrm{~s}$ for the sample size used for experimental purpose, however, in terms of sensory attributes they were inedible, due to significant moisture lost $50 \%, 56 \%$ and $75 \%$ at $170^{\circ} \mathrm{C}, 180^{\circ} \mathrm{C}$ and $190^{\circ} \mathrm{C}$, respectively.

The analysis of variance was conducted for the moisture content and oil uptake for the first $360 \mathrm{~s}$ of frying, data extrapolated in the corresponding linear regions for the two sets of curves (Figure 1 and Figure 2), and because cooking for longer times was observed to lead to the onset of deterioration of sensory qualities. These analyses show that moisture loss and oil uptake were significantly $(\mathrm{P}<0.05)$ influenced by frying time, and is dependent on the FOT. The synergy between the frying time and FOT has significantly $(\mathrm{P}<0.05)$ influenced moisture loss. The effect of temperature on the slopes of the time trends (forced through the origin) is evident in Table 1.

It is interesting to note that the effect of raising the FOT from $170^{\circ} \mathrm{C}$ to $180^{\circ} \mathrm{C}$ is far greater than the effect of the same incremental change to $190^{\circ} \mathrm{C}$. In the case of moisture loss, the latter increment has nevertheless, a noticeable effect on the slope, whereas in the case of oil uptake, the change in slope is negligible. Kassama and Ngadi [10], Gambleand Rice [8] observed a similar decreasing effect of higher frying oil temperatures on oil uptake in chicken breast meat and potato slices, respectively.

At a frying time of $900 \mathrm{~s}$, the mean fat uptakes by chicken breast were $6.84 \%, 11.87 \%$ and $10.53 \%$ dry basis $(\mathrm{db})$ at temperatures of $170^{\circ} \mathrm{C}, 180^{\circ} \mathrm{C}$, and $190^{\circ} \mathrm{C}$, respectively. Gupta et al. [21] reported fat uptakes of $15 \%$ and $>15 \%$ in French fries after 14 min frying at $\mathrm{A} 170$ and $180^{\circ} \mathrm{C}$, respectively. Ang and Miller [22] reported an oil content of $25.3 \%(\mathrm{wb})$ for deep-fat fried chicken. Since samples fried for $900 \mathrm{~s}$ were too dry to be edible, we decided to establish cook values, $\mathrm{C}$, to relate frying time to the organoleptic attributes of the material, prior to generating regression equations relating moisture

Table 1. Trends in oil uptake and moisture loss of chicken during DFF at different FOTs during the first phase of frying ( 0 to $360 \mathrm{~s}$ ).

\begin{tabular}{ccl}
\hline Variables & Frying oil temperature $\left({ }^{\circ} \mathrm{C}\right)$ & Equation \\
\hline Moisture loss & 170 & $X=0.056 t$ \\
& 180 & $X=0.083 t$ \\
& 190 & $X=0.099 t$ \\
\hline Oil uptake & 170 & $y=0.021 t$ \\
& 180 & $y=0.041 t$ \\
& 190 & $y=0.042 t$
\end{tabular}

Where, $X$ is moisture loss (\%), $y$ is oil uptake (\%), $t$ is the frying time (s). 
loss and fat absorption to frying time and frying oil temperature.

\subsection{Cook Value}

The evolution of the chicken slabs center temperature during deep-fat frying is shown for the three frying oil temperatures in Figure 3. The frying oil temperature did not have a significant $(\mathrm{P}<0.05)$ influence on the center temperature, Kassama [1] reported similar observation in poultry; and indeep-fat fried potatoes by Pravisanaand Calvelo [23]. The high frying oil temperatures significant affect the rate of the moving energy boundary as it advances to the geometric center of the sample, however the center temperature remain fairly constant at $\left(\mathrm{T}=108^{\circ} \mathrm{C}\right)$. Similarly, even at the highest temperature $\left(190^{\circ} \mathrm{C}\right)$, the center temperature tended to stabilize at $108^{\circ} \mathrm{C}$. Fitting the experimental data of Figure 3 into Equation (1), the center temperature of the slab was estimated as a function of time.

The results of the analysis revealed $300 \mathrm{~s}$ as the ideal endpoint of cooking, hence the best frying time for all FOT. Based on this time (300 s), the reference temperature $\left(T_{r}\right)$ was computed as $100^{\circ} \mathrm{C}$ and the $\mathrm{C}$-value (C) is $415 \mathrm{~s}$. Frying for this amount of time will ensure microbial safety without affecting the sensory quality of fried products [24]. The data allows the estimation of the minimum frying time needed to ensure sufficient cooking at the center of the slab, thus once the center is cooked, the rest of the strip will attain a c-value greater than $415 \mathrm{~s}$. Therefore, the plot of the C-value versus frying time (Figure 4) shows frying time for chicken breast should not be less than $300 \mathrm{~s}$. On the other hand, by inspection of Figure 3 it shows that only $30 \%$ of the frying time is required for the center temperature to reach $108^{\circ} \mathrm{C}$, this of course is dependent on the thickness of the sample and frying temperature.

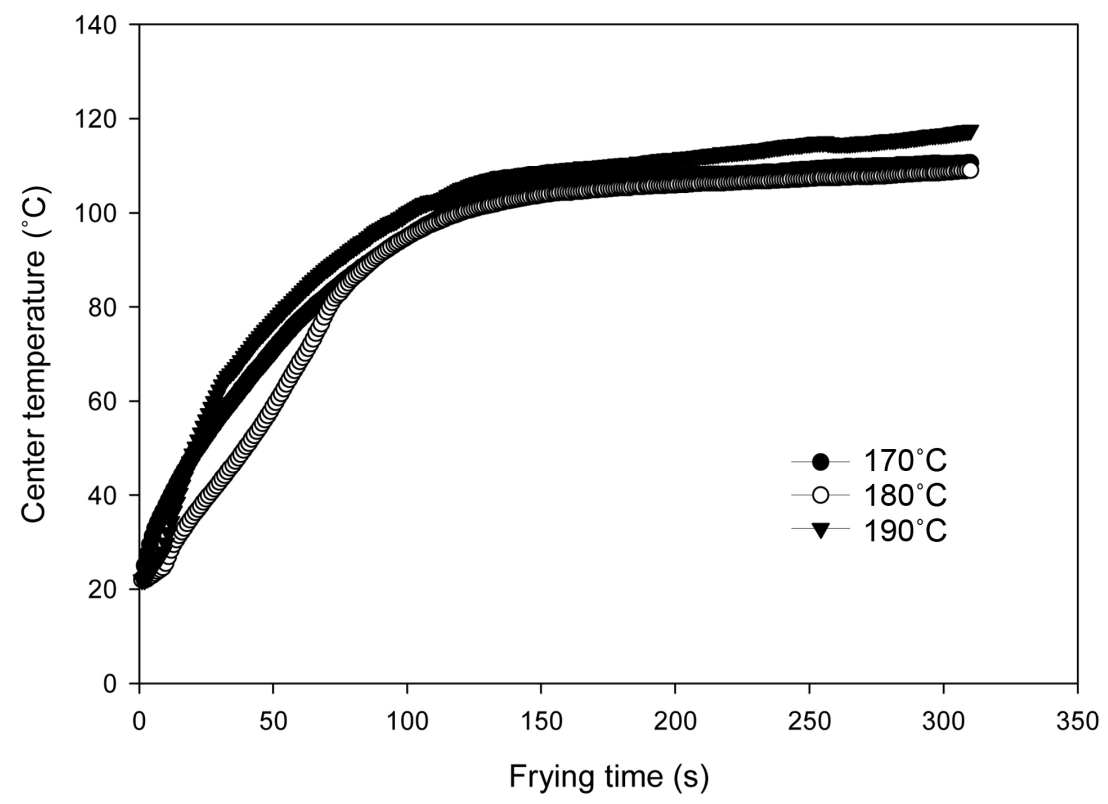

Figure 3. Thermal histories of the chicken breast slab center for different oil temperatures during deep-fat frying. 


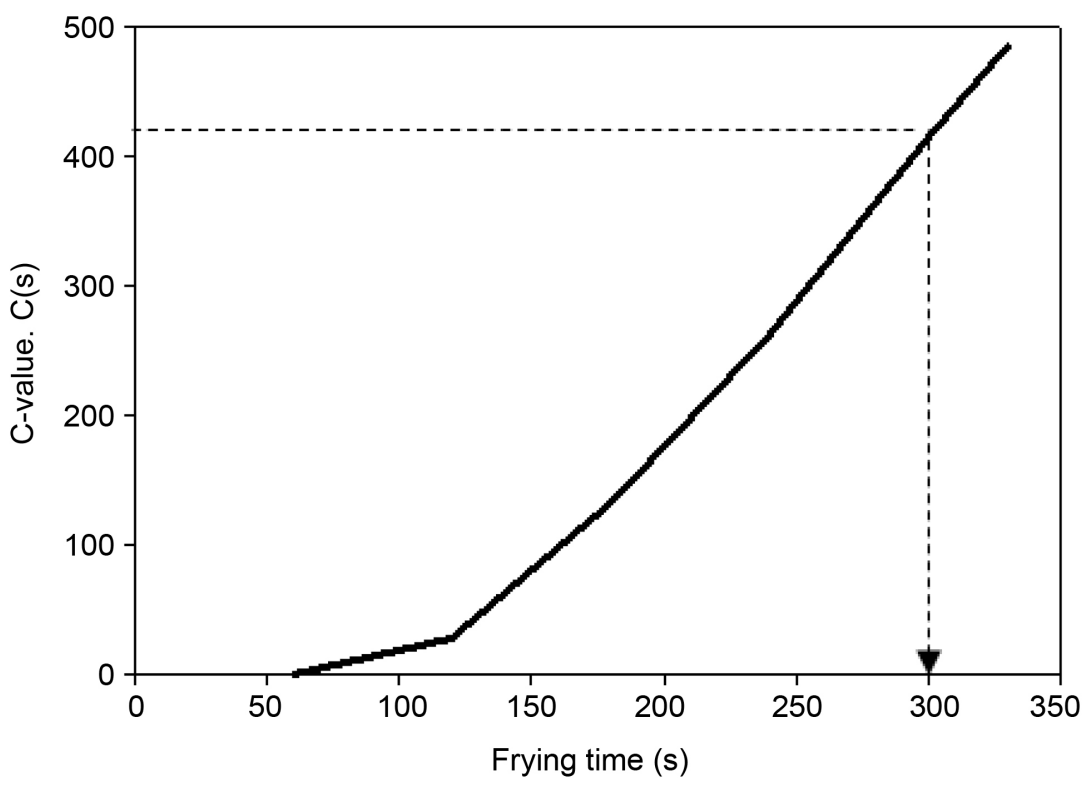

Figure 4. Cook value at the chicken breast slab center as a function of frying time.

\subsection{Correlation between Fat Uptake and Moisture Content}

The relationship between oil uptake and moisture loss (Figure 5(a)) closely resembles the curve shown in Figure 2(b). This is expected due to relationship between moisture loss and time (Figure 1(b)) which is reasonably linear over the frying times greater than $45 \mathrm{~s}$.

The result indicated that the oil uptake is linearly related to moisture loss, however this relationship only exist when the moisture content is $<40 \%$ at all frying oil temperatures. Oil uptake then appears to stabilize in the quasi-equilibrium state and fluctuate to the end while the moisture continues the leave the product as the cooking continues [10] [25]. In contrast, Gambleand Rice [8] reported that oil uptake was directly proportional to moisture content over the full range of moisture content (1\% to $80 \%$ ) in thick slice potatoes $(1.5 \mathrm{~mm})$. Although, our results may differ due to the inherent differences of the pore structure and the pore size distribution of the products, however, the limiting factor to the transport mobility of moisture and oil observed may not have been detectable in much thinner slabs.

The fluctuations of the oil uptake at the later stages $(\mathrm{MC}>40 \%)$ of frying as shown in Figure 5(b) may be due to the temporal interaction between oil intrusion and water vapor build-up. The infiltration of oil may block the capillary blind pores that are not connected through the pore structure network. Whereas, oil blocking the contiguous pores connected to the pore network may be relieved once there is sufficient pressure build-up to free the capillary pathway. Changes on the pore structure may have also contributed to this behavior, but was not monitored in this experiment. The rate (1.64 and $1.74 \mathrm{~g} / \mathrm{s}$ ) of oil uptake between $180^{\circ} \mathrm{C}$ and $190^{\circ} \mathrm{C}$, respectively are very similar, thus varies significantly $(\mathrm{P}<0.05)$ from $1.35 \mathrm{~g} / \mathrm{s}$ at $170^{\circ} \mathrm{C}$ as shown in Table 2 . Gamble and Rice [8] reported that the rate oil uptake in potato slices is much lower at lower FOT 


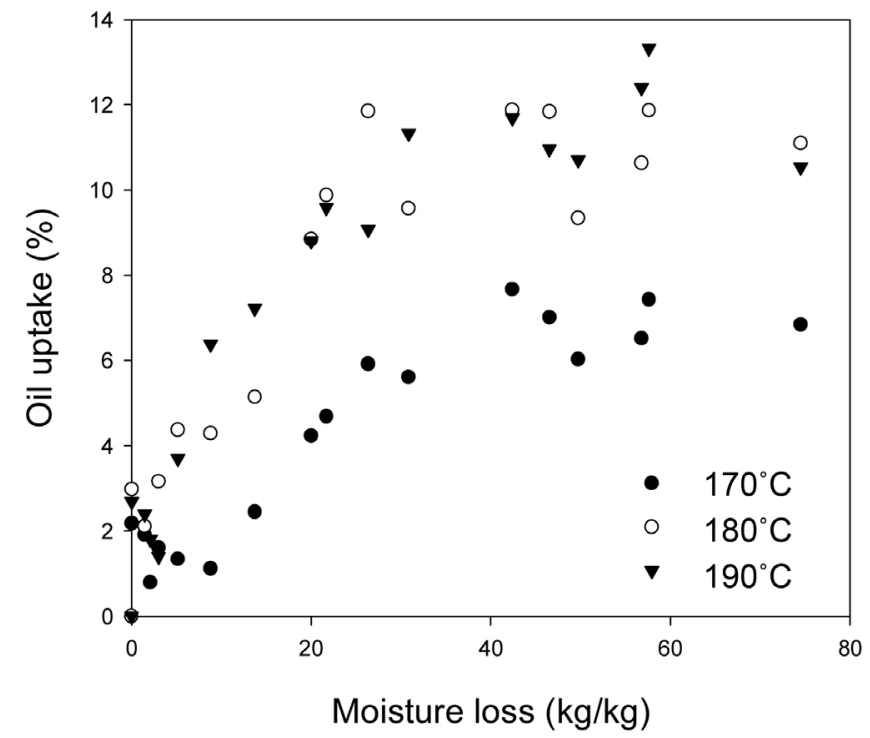

(a)

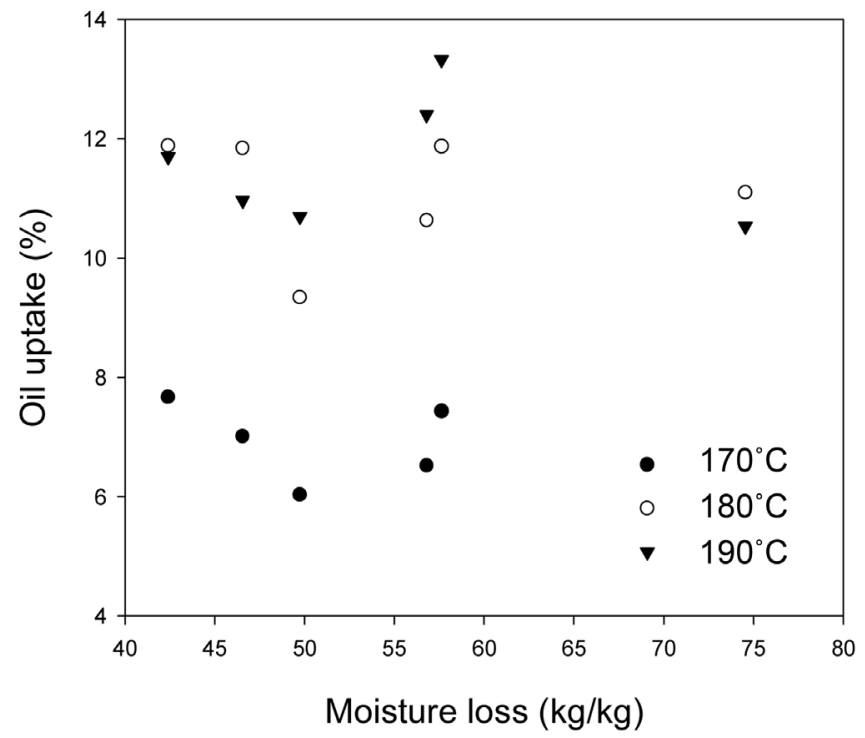

(b)

Figure 5. Oil uptake as a function moisture loss in chicken breast meat during deep-fat frying.

Table 2. Regression equations for oil uptake as a function of moisture loss of chicken breast meat during deep-fat frying at different frying temperatures.

\begin{tabular}{ccc}
\hline Temperature $\left({ }^{\circ} \mathrm{C}\right)$ & Regression equation & Correlation coefficient \\
\hline 170 & $y=1.35+0.24 x$ & 0.73 \\
180 & $y=1.64+0.39 x$ & 0.85 \\
190 & $y=1.74+0.33 x$ & 0.92 \\
\hline
\end{tabular}

$y=$ oil uptake; $x=$ Moisture loss.

and then increases with increased FOT.

\section{Conclusion}

This study shows strong linear relationship between oil uptake and moisture loss during deep-fat frying of chicken breast. The effect of frying oil temperature on oil absorption is significant $(\mathrm{P}<0.05)$ but is likely close to a maximum at the frying oil temperatures used in this study. The data indicate that oil absorption reaches a plateau or quasiequilibrium in the vicinity of $35 \%-40 \%$ moisture loss. This is contrast to the linear relationship between oil uptake and moisture content over a full range of moisture content reported for thin potato. The quasi-equilibrium or fluctuations of oil uptake as moisture loss progresses beyond $40 \%$ tend to equilibrate while moisture loss continued in the quasi-equilibrium state. The relationship between moisture loss and oil uptake is an important phenomenon in the context of characterizing the physical properties of fried product.

\section{Acknowledgements}

The authors acknowledge the Natural Sciences and Engineering Research Council of 
Canada (NSERC), and the Alabama Agricultural \& Mechanical University Experimental Station, Normal, Alabama for providing financial assistance to support this research project.

\section{References}

[1] Kassama, L.S. (2003) Pore Development in Food during Deep-Fat Frying. Ph.D. Dissertation, McGill University, Montreal.

[2] Pambou-tobi, N., Arab-Tehrany, E. and Niamayoua, R.K. (2016) RSM Applied for Optimization of Deep-Fat Fried Ripe Plantain Slices and Study of Oxidation Kinetics of Oil by DSC and Polar Methods. Journal of Food Science and Technology, 53, 269-280. http://dx.doi.org/10.1007/s13197-015-2021-y

[3] Saguy, I.S. and Pinthus, E.J. (1995) Studies Designed to Gain an Understanding of How Oil Is Absorbed by Foods during Deep-Fat Frying Can Lead to Improved Products and Processes. Food Technology. Presented at a Symposium Sponsored by the IFT Food Engineering Division, 142-145.

[4] Rahimi, J. and Ngadi, M.O. (2015) Surface Ruptures of Fried Batters as Influenced by Batter Formulations. Journal of Food Engineering, 152, 50-56.

http://dx.doi.org/10.1016/j.jfoodeng.2014.12.002

[5] Wang, Y., Ngadi, M.O. and Adedeji, A.A. (2010) Shrinkage of Chicken Nuggets during Deep-Fat Frying. International Journal of Food Properties, 13, 404-410. http://dx.doi.org/10.1080/10942910802626721

[6] Balasurbramaniam, V.M., Chinnan, M.S., Mallikararjunan, P. and Phillips, R.D. (1997) The Effect of Edible Film on Oil Uptake and Moisture Retention of a Deep-Fat Fried Poultry Product. Journal of Food Engineering, 20, 17-29. http://dx.doi.org/10.1111/j.1745-4530.1997.tb00408.x

[7] Kassama, L.S. and Ngadi, M.O. (2004) Pore Development in Chicken Meat during Deep-Fat Frying. LWT Food Science and Technology, 37, 841-847. http://dx.doi.org/10.1016/j.lwt.2004.03.010

[8] Gamble, M.H. and Rice, P. (1987) Effect of Pre-Fry on Oil Uptake and Distribution in Potato Chip Manufacture. International Journal of Food Science and Technology, 22, 535-548. http://dx.doi.org/10.1111/j.1365-2621.1987.tb00519.x

[9] Mittelman, N., Mizrahi, S.H. and Berk, Z. (1982) Heat and Mass Transfer in Frying. In: Mckenna, B.M., Eds., Engineering and Food, Elsevier Applied Science Ltd, UK, 109-116.

[10] Kassama, L.S. and Ngadi, M.O. (2005) Pore Development and Moisture Transfer Inn Chicken Meat during Deep-Fat Frying. Drying Technology, 23, 905-923.

http://dx.doi.org/10.1081/DRT-200054239

[11] Krokida, M.K., Oreopoulou, V. and Maroulis, Z.B. (2000) Water Loss and Oil Uptake as a Function of Frying Time. Journal of Food Engineering, 44, 39-46. http://dx.doi.org/10.1016/S0260-8774(99)00163-6

[12] Moreira, R.G., Castell-Perez, M.E. and Barrufet, M.A. (1999) Deep-Fat Frying: Fundamentals and Applications. Aspen Publishers Inc., MD.

[13] Singh, R.P. (1995) Heat and Mass Transfer in Foods during Frying. Food Technology. Presented at a Symposium Sponsored by the IFT Food Engineering Division, 134-137.

[14] Keller, C.F. and Escher, F. (1989) Heat and Mass Transfer during Deep Fat Frying of Potato Products. International Congress on Engineering and Food, Cologne, 25 May-1 June 1989.

[15] Leonard, S., Luh, B.S. and Simone, M. (1964) Aseptic Canning of Foods: 1. Preparation and 
Processing Procedures. Food Technology, 18, 81.

[16] Dagerskog, M. (1977) Time-Temperature Relationships in Industrial Cooking and Frying. In: Hoyem, T. and Kvale, O., Eds., Physical, Chemical and Biological Changes in Food Caused by Thermal Processing, Applied Science Publishers Ltd., London, 77-100.

[17] AOAC (1995) Official Methods of Analysis. AOAC International, Gaithersburg.

[18] AOAC (1990) Official Methods of Analysis. Association of Official Analytical Chemists, Washington DC.

[19] Bouchon, P., Hollins, P., Pearson, M., Pyle, D.L. and Tobin, M.J. (2001) Oil Distribution in Fried Potatoes Monitored by Infrared Microspectroscopy. Journal of Food Science, 66, 918923. http://dx.doi.org/10.1111/j.1365-2621.2001.tb08212.x

[20] Jezek, D., Brncic, M., Brncic, S.R., Karlovic, S., Bosiljkov, T., Tripalo, B., Karlovic, D., Sipusic, J. and Pukec, D. (2009) Porosity of Deep Fat Fried Breaded Chicken Meat. Food Technology and Biotechnology, 47, 389-395.

[21] Gupta P., Shivhare, U.S. and Bawa, A.S. (2000) Studies on Frying Kinetics and Quality of French Fries. Drying Technology, 18, 311-321. http://dx.doi.org/10.1080/07373930008917706

[22] Ang, J.F. and Miller, W.B. (1991) Multiple Functions of Powdered Cellulose as a Food Ingredient. Cereal Foods World, 36, 558-564.

[23] Pravisani, M.F. and Calvelo, A. (1986) A Minimum Cooking Time for Potato Strip Frying. Journal of Food Science, 51, 614-617. http://dx.doi.org/10.1111/j.1365-2621.1986.tb13892.x

[24] Krokida, M.K., Oreopoulou. V., Maroulis, Z.B. and Marinos-Kouris, D. (2001) Deep-Fat Frying of Potato Strips-Quality Issues. Drying Technology, 19, 879-935. http://dx.doi.org/10.1081/DRT-100103773

[25] Ngadi, M.O., Watts, K.C. and Correia, L.R. (1997) Finite Element Method Modeling of Moisture Transfer in Chicken Drums during Deep-Fat Frying. Journal of Food Engineering, 32, 11-20. http://dx.doi.org/10.1016/S0260-8774(97)00095-2

Submit or recommend next manuscript to SCIRP and we will provide best service for you:

Accepting pre-submission inquiries through Email, Facebook, LinkedIn, Twitter, etc. A wide selection of journals (inclusive of 9 subjects, more than 200 journals)

Providing 24-hour high-quality service

User-friendly online submission system

Fair and swift peer-review system

Efficient typesetting and proofreading procedure

Display of the result of downloads and visits, as well as the number of cited articles Maximum dissemination of your research work

Submit your manuscript at: http://papersubmission.scirp.org/ 